\title{
TUGAS FILSAFAT PANCASILA
}

KHASUS PEMBUNUHAN PRIA DALAM PLASTIK DI CIANJUR TUJUH ORANG TERSANGKA

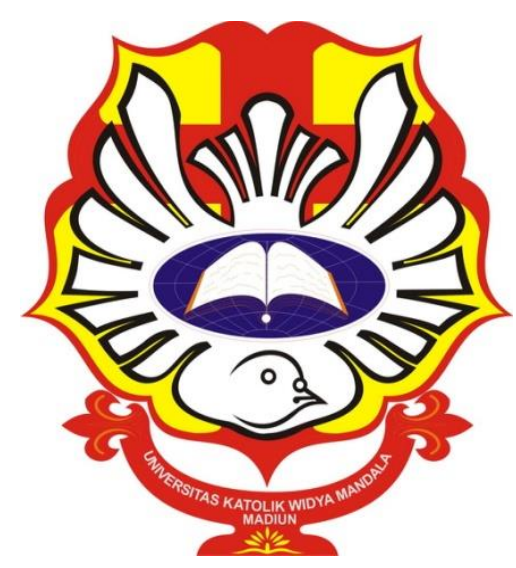

Disusun Oleh:

Hermanto

NIM 3903019029

FAKULTAS EKONOMI/BISNIS

JURUSAN MANAJEMEN

UNIVERSITAS KATOLIK WIDYA MANDALA MADIUN

MADIUN 2019 


\begin{abstract}
ABSTRAK
Dalam kasus saat ini juga mencakup banyak hal yang melanggar normanorma dan pancasila,sebagai bangsa indonesia kita harus saling mengasihi sesama umat manusia satu sama lain. Tim Khusus Satreskrim Polres Cianjur menangkap tujuh orang yang diduga terlibat dalam kasus pembunuhan Jaenal (43 th), pria yang jenazahnya terbungkus plastik di tebing di wilayah Kecamatan Sukanagara, Cianjur, Kamis (26/9/2019). Dari kasus ini pelanggaran sila pertama“Ketuhanan Yang Maha Esa”. Kita sebagai manusia harus menghargai sesama umat manusia dan setiap ciptaan-Nya.

Kasus ini juga melanggar sila kedua "Kemanusiaan yang Adil dan Beradab".Sebagai rakyat Indonesia yang berlandaskan Pancasila seharusnya memiliki sikap tanggung jawab dan tenggang rasa, saling mencintai sesama umat manusia, tidak semena- mena terhadap orang lain dan menjujung tinggi nilai kemanusiaan, dari kasus ini juga bahwa membunuh adalah suatu hal yang sangat kejam jadi dalam negara indonesia ini harus juga bersifat hukum dan . Dalam kasus pembunuhan pembunuhan Jaenal (43 th), pria yang jenazahnya terbungkus plastik di tebing di wilayah Kecamatan Sukanagara, dalam khasus tersebut perilaku ini sangat kejam sampai dia membunuh dan membungkusn jenasah Jaenal tersebut.
\end{abstract}

Kasus ini juga mencakup dalam pola pikir yang tumpul sampai membunuh dan membungkus jenasah korban yang bernama jaenal tersebut dengan plastik. Kasus ini juga menjadi pembelajaran bagi bangsa indonesia harus menjunjung tinggi nilai pancasila dan norma-norma yang berlaku untuk dapat mencerminkan dalam kehidupan sehari-hari. Masyarkat indonesia juga harus berperilaku adil,tegas dan jujur ,dan juga menjunjung tinggi nilai kemanusiaan dengan melakukan kegiatan kemanusiaan didalam lingkungan masyarakat . 


\section{A. KHASUS PEMBUNUHAN PRIA DALAM PLASTIK DI CIANJUR TUJUH ORANG TERSANGKA}

Sumber ", https://regional.kompas.com/read/2019/10/14/09543071/kasu pembunuhanpria-dalam-plastik-di-cianjur-ini-peran-tersangka?page=all.

KOMPAS.com - Tim Khusus Satreskrim Polres Cianjur menangkap tujuh orang yang diduga terlibat dalam khasus pembunuhan Jaenal (43), pria yang jenazahnya terbungkus plastik di tebing di wilayah Kecamatan Sukanegara, Cianjur, Kamis (26/9/2019).

Mereka adalah ANA (50), CK (42), W (43), SP (37), D (41), AT (43) dan Y (54). Dari ketujuh pelaku, ANA dan CK ditetapkan sebagai tersangka utama. Keduanya diduga kuat sebagai pembunuh korban yang merupakan warga Batujajar, Kabupaten Bandung Barat. Sedangkan lima tersangka lainya berperan sebagai penadah dan perantara penadah barang-barang milik korban, yakni sepeda motor yang dijual pelaku utama. "Tersangka ANA dan CK ini sebagai eksekutor yang menghabisi myawa korban. Diduga mengunakan kayu balok yang sudah kita amankan bersama barang bukti lainnya," kata Paur Subbag Humas Ipda Budi Setiayuda dalam keterangan tertulis yang diterima, Minggu (13/10/2019). Baca juga: khasus pembunuhan pria Dalam Plastik di Canjur Terungkap, 7 pelaku ditangkap penangkapan para tersangka berdasarkan petunjuk dan hasil oleh tempat kejadian perkara, serta pengembangan informasi yang didapat dari keterangan sejumlah saksi.

Awalnya, polisi menangkap ANA kemudian CK. Setelah dikembangkan, polisi menangkap lima tersangka lainya. Dari tangan para tersangka diamankan sejumlah barang bukti yang ditahan oleh polisi., yaitu satu untit mobil, dua unit sepeda motor, sebatang kayu balok yang diduga dugunakan tersangka utama untuk menghabisi nyawa korban, dan sejumblah ponsel. "Terkait motifnya masih dialami oleh penyidik.

Hasil nanti akan kita sampaikan segera, "ujar dia. Sebelumnya doberitakan, warga dihebohkan dengan penemuan mayat di tepi tebing di Kampung Sukarajin RT 001/008, Desa Sukamekar, Kecamatan Sukanagara, Kabupaten Cianjur, Jawa Barat, Kamis (26/9/2019). Baca juga : Berkat Jagung Warna-warni, Petani Cianjur Jalin Kerja Sama dengan Malaysia Mayat tanpa identitas yang nyaris tinggal tulang belulang itu diduga sudah berada dolokasi selama sepekan. Pihak kepolisian menyebutkan, mayat 
tersebut diduga korban pembunuhan karena dari hasil visum bagian luar ditemukan adanya bekas tindakan kekerasan.

\section{B. TEORI PANCASILA SEBAGAI FILSAFAT}

Pancasila adalah filsafat negara yang lahir sebagai ideologi kolektif (cita-cita bersama) seluruh bangsa Indonesia. pancasila dikatakan sebagai filsafat karena merupakan hasil perenungan jiwa yang mendalam yang dilakukan oleh para pendahulu kita, yang kemudian dituangkan dalam suatu sistem yang tepat. Notonagoro berpendapat bahwa filsafat pancasila ini memberikan pengetahuan dan pengertian ilmiah yaitu tentang hakikat pancasila.

Jika dilihat dari soal tempat, filsafat pancasila merupakan bagian dari Filsafat Timur (karena Indonesia kerap digolongkan sebagai Negara yang ada di belahan bagian Timur). Sebenarnya, ada banyak nilai ketimuran yang termuat dalam Pancasila, misalnya soal pengakuan akan adanya Tuhan, kerakyatan, keadilan yang diidentikan dengan paham mengenai 'ratu adil' dan seterusnya. Pancasila juga memuat pahampaham Barat, seperti : Kemanusiaan, demokrasi, dan seterusnya. Sebagai sistem filsafat, Filsafat Pancasila ternyata juga harus tunduk dalam formulasi Barat yang sudah mapan sejak dulu. Jika Pancasila mau dipertanggungjawabkan secara salih, logis, koheren, dan sistematis, di dalamnya harus memuat kaidah-kaidah filosofis. Pancasila harus memuat juga dimensi metafisis, (ontologis), epistomologis, dan aksiologis.

Pertama, secara ontologis kajian Pancasila sebagai filsafat dimaksudkan sebagai upaya untuk mengetahui hakikat dasar dasar Pancasila. Menurut Notonagoro, hakikat dasar ontologis Pancasila adalah manusia, karena manusia ini yang merupakan subjek hukum pokok sila-sila Pancasila. Pancasila sebagai dasar filsafat. Pancasila sebagai dasar filsafat negara Republik Indonesia memiliki susunan lima sila yang merupakan suatu persatuan dan kesatuan serta mempunyai sifat dasar kesatuan yang mutlak, yang berupa sifat kodrat monodualis yaitu sebagai makhluk individu sekaligus juga sebagai makhluk sosial, serta kedudukannya sebagai makhluk pribadi yang berdiri sendiri sekaligus juga sebagai makhluk Tuhan.

Kedua, kajian epistemologi Filsafat Pancasila dimaksudkan sebagai upaya untuk mencaru hakikat Pancasil sebagai suatu sistem pengetahuan. Hal ini dimungkinkan adanya karena epistemologi meupakan bidang filsafat yang membahas hakikat ilmu pengetahuan (ilmu tentang ilmu). 
Ketiga, kajian aksiologi Filsafat Pancasila pada hakikatnya membahas nilai praksis atau manfaat suatu pengetahuan mengenai Pancasila. Hal ini disebabkan karena sila-sila Pancasila sebagai suatu sistem filsafat memiliki satu kesatuan dasar aksiologi, nilai-nilai dasar yang terkandung di dalam Pancasila pada hakikatnya merupakan suatu kesatuan yang utuh. Aksiologi Pancasila ini mengandung arti bahwa kita membahas filsafat nilai Pancasila. Secara aksiologi, bangsa Indonesia merupaka pendukung nilainilai Pancasila.

Pancasila sebagai bangsa dan negara Republik Indonesia mengandung makna bahwa setiap aspek kehidupan kebangsaan, kenegaraan dan kemasyarakatan harus didasarkan pada nilai-nilai ketuhanan, kemanusiaan, persatuan, kerakyatan, dan yang terakhir keadilan. Pemilkiran filsafat kenegaraan ini bertolak dari pandangan bahwa negara meupakan suatu persekutuan hidup manusia atau organisasi kemasyarakata, dimana merupakan masyarakat hukum. 


\section{MENGANALISA KASUS DENGAN TEORI/MENEROPONG TEORI FILSAFAT PANCASILA}

Ditinjau dari teori pancasila sebagai filsafat mengenai kasus perampokan disertai pembunuhan Tim Khusus Satreskrim Polres Cianjur menangkap tujuh orang yang diduga terlibat dalam kasus pembunuhan Jaenal (43), pria yang jenazahnya terbungkus plastik di tebing di wilayah Kecamatan Sukanagara, Cianjur, Kamis (26/9/2019).

Dari kasus ini termasuk pelanggaran pancasila sila pertama "ketuhanan yang maha esa" dimana dari sila ini menjelaskan bahwa Indonesia adalah rakyat beragama yang menekankan nilai-nilai agama dan karena manusia sebagai makhluk ciptaan Tuhan tidak memiliki hak untuk mencabut nyawa manusia lain. Manusia diciptakan Tuhan untuk saling mengasihi dan menyayangi satu sama lain. Di setiap agama tentunya mengajarkan mengenai kebaikan dan tata cara untuk dapat merinteraksi baik antar sesama agama.

Dari kasus ini sungguh menjadi keperihatinan sekali dimana bangsa indonesia banyak sekali sering terjadi tindak kejahatan setiap tahunnya yang dipengaruhi dengan teknologi dan pengaruh ekonomi. Setiap tahunnya pengganguran terus meningkat dan lapangan pekerjaan yang tidak sebanding dengan tenaga kerja yang dibutuhkan ini juga suatu menigkatnya tingkat kriminalitas yang terjadi di sumsel. Hal ini terjadi karena banyak pengaruh dari faktor ekonomi dan faktor lainnya. Selayaknya umat beragama harus saling menghargai dan mengasihi serta menebarkan kebaikan kepada sesama sesuai sila pertama yaitu "ketuhanan yang maha esa" bukan saling membunuh dan mengambil milikorang lain.

Dari kasus ini juga termasuk pelanggaran Pancasila kedua "Kemanusiaan yang Adil dan Beradab" dimana dalam sila kedua ini menjelaskan bahwa sebagai rakyat Indonesia selayaknya memperlakukan setiap manusia secara adil dan beradab dengan cara saling mencintai sesama manusia, mengembangkan sikap tenggang rasa, tidak semena-mena terhadap orang lain dan menjujung tinggi nilai kemanusiaan. Dari sila kedua juga menjelaskan kita sebagai umat manusia seharusnya saling mencintai sesama manusia dan memperlakukan manusia selayaknya manusia bukan sebaliknya yang dilakukakn pelaku dalam kasus "kasus pembunuhan Jaenal (43), pria yang jenazahnya terbungkus plastik di tebing di wilayah Kecamatan Sukanagara, Cianjur” sungguh ini tidak mencerminkan pada pancasila sila kedua. 
Dari kasus ini juga dapat diartikan bahwa kebutuhan manusia masih sangat kurang,Karena masih banyak pengangguran dinegara Indonesia sehingga mereka untuk mendapatkan uang dengan cara membunuh atau merampok untuk memenuhi segala kebutuhan kehidupan mereka sehari-hari.dari ini juga kita sebagai umat yang berperi kemanusiaan harus saling menghargai satu sama lain.

Kasus pembunuhan Jaenal (43), pria yang jenazahnya terbungkus plastik di tebing di wilayah Kecamatan Sukanagara, Cianjur jelas sekali melanggar sila pertama dan sila kedua yang berbunyi. Sila pertama "ketuhanan yang maha esa",sila kedua "kemanusiaan yang adil dan beradap" dimana pelaku dengan kejam dan ganasnya merenggut milik orang lain dengan cara yang tidak wajar serta membunuh ini adalah suatu perilaku yang tidak berprikemanusiaan. Sebagai rakyat indonesia kita harus mencerminkan nilai pancasila itu sendiri dalam kehidupan sehari-hari dan memiliki sikap toleransi kepada keberagaman indonesia bukan dengan cara merampok dan membunuh sehingga jenasah jaenal tersebut dibungkus dengan plastik di tebing di dekat sungai,seharusnya kita sesama bangsa indonesia harus saling menghargai atau menjaga satu dengan yang lainnya karena pancasila adalah pedoman kehidupan kebangsaan dan dasar negara indonesia. bangsa indonesia seharusnya memiliki kesadaran dan prilaku dengan nilai moral dan norma-norma yang ada. Dalam filsafat pancasila "Sebagai bangsa dan negara Republik Indonesia mengandung makna bahwa setiap aspek kehidupan kebangsaan, kenegaraan dan kemasyarakatan harus didasarkan pada nilai-nilai ketuhanan, kemanusiaan, persatuan, kerakyatan, dan yang terakhir keadilan”. Dari kasus pembunuhan jaenal (43), pria yang jenasahnya terbungkus plastik di tebing di wilayah Kecamatan Seuakagara ini melanggar nilai-nilai ketuhanan dan kemanusiaan.

Kasus ini juga menjadi pembelajaran bagi bangsa indonesia harus menjunjung tinggi nilai pancasila dan norma-norma yang berlaku untuk dapat mencerminkan dalam kehidupan sehari-hari. Masyarkat indonesia juga harus berperilaku adil,dan juga menjunjung tinggi nilai kemanusiaan dengan melakukan kegiatan kemanusiaan. Bangsa indonesia juga harus memberantas setiap bangsa indonesia yang melanggar nilai-nilai pancasila yang berlaku serta mentaati nilai norma agama yang berlaku disetiap masing-masing agama di indonesia.

Memiliki kesadaran untuk bersama membangun Indonesia menjadi lebih baik dan memberantas tindakan-tindakan yang melanggar hukum dan Pancasila. Agar peristiwa-peristiwa seperti ini tidak terjadi lagi di Indonesia. Indonesia dapat menjadi 
Negara sadar hukum bagi rakyatnya dan ini bukan perkerjaan pemerintah atau siapapun ini adalah tugas kita sebagai rakyat Indonesia agar Indonesia dapat menjadi Negara yang adil, damai dan sejahtera sekarang bahkan untuk selamanya. 


\section{KESIMPULAN}

Kasus pembunuhan Jaenal (43), pria yang jenazahnya terbungkus plastik di tebing di wilayah Kecamatan Sukanagara, Cianjur. Dari kasus ini pelanggaran sila pertama“Ketuhanan Yang Maha Esa”. Kita sebagai manusia harus menghargai setiap ciptaan-Nya. Kasus ini juga melanggar sila kedua "Kemanusiaan yang Adil dan Beradab".Sebagai rakyat Indonesia yang berlandaskan Pancasila seharusnya memiliki sikap tenggang rasa, saling mencintai sesama manusia, tidak semena-mena terhadap orang lain dan menjujung tinggi nilai kemanusiaan.

Bukan sebaliknya yang dilakukan oleh pelaku sungguh-sungguh perbuatan yang tidak mencerminkan Pancasila itu sendiri. dalam kasus diatas kita sebagai rakyat indonesia harus menjadi pedoman dalam kehidupan bangsa indonesia, dan juga sebagai pembelajaran agar kita bangsa indonesia dapat mentaati pancasila dan norma-norma lainnya.Dan juga sebagai umat yang beragama pula harus saling menghargai umat beragama yang lain agar dapat menjadi pedoman dalam masyarakat dan juga saling menolong masyarakat yang sedang dalam kesusahan. 


\section{REFERENSI}

Tersangka", https://regional.kompas.com/read/2019/10/14/09543071/kasuspembunuhan-pria-dalam-plastik-di-cianjur-ini-peran-7-tersangka?page=all.

Penulis : Kontributor, Cianjur Firman Taufiqurrahman

Editor : David Oliver Purba (Diakses tanggal 02 November 2018)

Dewantara, Agustinus W. 2017. Diskursus Filsafat Pancasila Dewasa Ini. Yogyakarta: PT. Kanisius.

Taufiqurrahman

Dewantara, A. (2017). Diskursus Filsafat Pancasila Dewasa Ini.

Dewantara, A. (2017). Filsafat Moral (Pergumulan Etis Keseharian Hidup Manusia).

Dewantara, A. (2017). Alangkah Hebatnya Negara Gotong Royong (Indonesia dalam Kacamata Soekarno).

DEWANTARA, AGUSTINUS WISNU, M. A. Lasiyo, and Sri Soeprapto. GOTONGROYONG MENURUT SOEKARNO DALAM PERSPEKTIF AKSIOLOGI MAX SCHELER, DAN SUMBANGANNYA BAGI NASIONALISME INDONESIA. Diss. Universitas Gadjah Mada, 2016.

Dewantara, A. W. (2015). PANCASILA SEBAGAI PONDASI PENDIDIKAN AGAMA DI INDONESIA. CIVIS, 5(1/Januari). 